УДК: $811.163 .41 ’ 38$

DOI: https://doi.org/10.18485/belic_slv.2018.3.ch7

Јелена Јовановић Симић

\title{
БЕЛИЋ О СТИЛИСТИЦИ, И О СТИЛИСТИЦИ СРПСКОГ ЈЕЗИКА
}

\section{1. Уводне напомене}

1. Издавањем Белићевих „Изабраних дела” на прелому прошлог и нашега века умногоме је олакшан приступ радовима овог знаменитог научника, којима је обележено стварно формирање и консолидација српске науке о језику и њено оспособљавање за велике теоријске и практичне подухвате, посебно у правцу дијалектолошких, језичкоисторијских и лексикографских испитивања српског језика, али и у другим смеровима.

а) М. Стевановић, Р. Бошковић, И. Поповић, Р. Симић и други настављају Белићеве идеје правом линијом успона, а двоје Ивића, А. Младеновић и њихови следбеници то чине доносећи често свеже теоријске ставове и аналитичке поступке, и делом ширећи хоризонте српских научних интересовања и ван националног амбијента, и радећи још један важан национални посао који је започео Белић: изводећи нашу лингвистику одлучно на међународну сцену.

б) Ваља овде бар узгред поменути Ј. Вуковића и сарајевски огранак српске лингвистике, који из других праваца удахњује свежину лингвистичким идејама, и шири теоријска и практична истраживања и на тим странама српског језичког подручја.

2. Наш задатак у овом прилогу има уже домете од горе оцртаних, и тиче се стилистике и стилистичких интересовања Белићевих, како на чисто теоријском, тако исто и на истраживачком плану његова рада.

а) Два дела наслова: „о стилистици, и о стилистици српског језика” односе се заправо на та два правца стилистике у Белићевом делу. На једној страни су његови текстови о питању стила и стилистике уопште, а на другој аналитички и синтетички ставови о српском језику које Белић не насловљава као стилистичке, нити расправу води као стилистичку, али они заправо у целини, или бар делимично, леже на терену стилистике како је ми данас схватамо. 
б) Треба напоменути да је Белић своју пажњу поклањао стилистици и педесетих година XX века, када је у свету привремено постало владајуће схватање ${ }^{1}$ о непотребности и застарелости стилистике, коју је требало да замени теорија књижевности.

\section{2. Преглед теоријских идеја и решења}

1. Два Белићева рада - „Стилистика и граматика” и „Стилистика у светлости женевске школе” - и насловом и садржајем задиру у централна питања науке о стилу како је у Белићево време ова схватана.

1.1. У првом од два чланка Белић најпре помиње најистакнутија имена тадашње науке о језику и њихове главне радове: Карла Фослера и његовог италијанског следбеника Бенедета Крочеа, за које је целокупна наука о језику заправо стилистика, одн. естетика (исп. Симић 1997: 263-266; 254-255), те Леа Шпицера (Stilstudien 1918), Шарла Балија, В. Виноградова и др., али у разматрање узима и студију J. Риса о синтакси (1927), и то оне делове у њој који се односе на стилистику.

a) Рис, по Белићу (1998: 535), разликује вањску од унутрашње стилистике, одн. по његовом: 'објективну' од 'субјективне'. „У првом случају она испитује стил уколико се он тиче садржине и намене и циља неког дела, а у другом - уколико се стил налази у зависности од индивидуалних пишчевих особина".

б) Објективна или вањска стилистика - испитивала би заправо са̂мо дело, његове естетске и друге уметничке особености као предмета по себи, али и с обзиром на начин активирања језичких елемената узетих из система и поређених са системом, свакако и нормом. То излази и из Рисових речи ${ }^{2}$ које наводи Белић. Стилистика се по томе занима заправо за граматичке категорије, има дакле исти предмет као граматика, али приступајући језику полази из другог угла:

Да ли се на пр. која реч, који обрт, положај речи у реченици, каква конструкција често или ретко употребљавају, да ли што чини правило или је изузетак, да ли припада општој употреби или не, да

1 То је схватање убрзо превладано новим таласом пре свега функционалностилистичких истраживања који је запљуснуо Запад из правца тадашњег Совјетског Савеза и других земаља социјалистичког блока, и поновног рађања интереса да се ова наука појмовно и методолошки дефинише. Исп. Симић 1993.

2 Наводимо их у Белићевом преводу. 
ли је што безбојно или покрајинско, народски речено или речено у поверљивом тону, отмено, са пуно поезије или украса итд. - све то чини подједнако предмет и граматике и стилистике. Али граматика испитује све то само због тога што то чини део значења речи; стилистика међутим износи како се слаже садржина дела са изабраним језичким средствима, како стоје различне врсте и намене дела̂ према различно обојеној језичној грађи и њеним различним облицима. Граматика испитује и описује значења у свима њиховим преливима; стилистика пак испитује захтеве које различна намена језичког приказивања ставља њиховим могућим облицима и суди, да ли је у појединостима избор добро учињен, да ли је употреба чега тачна или није, да ли је 'у стилу' или није (Белић 1998: 536).

1.2. У области унутрашње или 'субјективне' стилистике - „Рис под извесним углом посматрања не налази никакве разлике између граматичког описа једног дела и стилистичког; јер кад се одбије прво све оно што иде у објективну стилистику, онда се испитивање појединачног стила којег писца или каквог дела своди на разлике у њихову језику према ономе што је обично и што други употребљавају":

У оскудици или богатству речника или једног дела његова; у избегавању конкретног или апстрактног, именичког или глаголског исказивања мисли; у претпостављању активне конструкције пасивној, слободнијег неслободнијем, аналитичког синтетичком реду речи, паратаксичке хипотаксичкој реченичној вези; краткоће и сажетости реченичне богато развијеним, уметнички испреплетаним периодима итд. Шта би од тога смела граматичка обрада занемарити, шта би од тога смело недостајати у потпуној граматици? (Исто м.).

a) И оволико је довољно да увидимо колико је сужен простор који Рис додељује стилистици, и колико стварно стилистика пружа недоумица аутору - односно колико је лутања било у одређењу предмета и научне методологије науке о стилу код Риса и његових савременика (у првој половини XX века). Стилистика је помоћна наука потчињена граматици, и само усредсређена - у својој објективно усмереној варијанти - на нормативност и естетску коректност израза као опште језичке појаве; - а у субјективној - на понашање појединца у том смеру посматраног, и особености конкретног израза.

б) У неку руку се таква проучавања данас - када још није до краја сагледан значај и позиција стилистике у систему наука о знаковним сис- 
темима и структурама - сврставају у област лингвистичке стилистике схваћене у уском смислу као пандан граматике.

2. Други Белићев рад за предмет заправо има учење Шарла Бајија $(1951)^{3}$, ученика Де Сосирова и настављача Де Сосирових лингвистичких истраживања.

2.1. По Бајију, предмет стилистике, исто као и лингвистике, јесте језички систем, а не индивидуална употреба конкретних јединица. Но стилистика се занима не за језик књижевности, који одражава тежњу уметника да створи естетски вредно дело (што је предмет естетике), већ разговорни књижевни језик етаблиран у (француским) интелектуалним круговима. И даље: тај језички идиом стилистика посматра из посебног угла, интересујући се за његова 'афективна' својства.

а) „Према томе - утврђује А. Белић, - када се о нечем мисли хладно и објективно, имамо један начин изражавања који би се могао назвати интелектуалним: на пр.: 'учините то'; 'желим да то учините' (без нарочитог повишавања тона); али ако унесемо елементе осећајности наше, изрази постају друкчији: 'За бога! учините то', 'Зар то да ми одбијете!', 'Ox, реците да ћете то учинити!' и сл.

б) Материјал друге врсте, оно што се тиче наших емоција, она изражајна средства у којима се крије афективни део садржаја, изрази наше осећајности и утицаји њихови на нашу осећајност, ето то улази, по схватању Балијеву, у стилистику. Ако назовемо интелектуално изношење факата логичким или мисаоним, онда би изношење осећајне или емоционалне стране разговорног језика једног друштва био предмет његове стилистике" (Белић 1998: 543).

2.2. Белић затим даје нешто као образложење Бајијеве дефиниције предмета стилистике, почевши од тврдње о постанку и развоју францускога књижевног језика радом великих стваралаца XVII, XVIII, XIX, и нарочито почетка XX в. Сви они „служе не само као духовна енергија за целокупни даљи развитак француског књижевног језика него и француским писцима често као непосредни углед”.

Отуда излази да је карактер францускога књижевног језика традиционалан и индивидуалан у исто време. Требало је за њега наћи као критеријум неки општији форум, нешто објективније што у исто време не отступа много од тога књижевног језика, што је из његова круга. То је језичко осећање француског друштва које прерађује у себи материјал књижевног језика, узима оно из њега што

3 Исп.: Симић 1997: 228-232. 
му одговара и даје му опште, заједничко обележје. На тај се начин уклањало из те основице оно што је индивидуално, оно што се противи заједничком или општем језичком осећању или што га вређа. Тако се дошло до неког 'чистилишта' свих индивидуалних књижевних језика, до негог општенародног прерађивања и престилизовања оног материјала који су у општу творионицу књижевног језика убацила различна времена, различни индивидуални таленти и толико различни по теми и обради дела (Белић 1998: 544).

a) Оправдавши тако Бајијеву одлуку да на показани начин дефинише стилистику француског језика, Белић прелази на српске прилике, и утврђује разлике између српских и француских општих и културних прилика, па и карактера књижевног језика насталог у тим специфичним условима. Оцртавши укратко постанак, развој и општи карактер Вуковог „народног књижевног језика” - Белић директно пореди ове две формације и дефинише српску ситуацију:

Ако испоредимо ове две концепције језичких и стилистичких мерила, за француски језик у тумачењу Балијеву, и за наш књижевни језик, онако како је он остварен у реформи Караџићевој, - одмах ћемо видети и велику сличност између њих и извесну разлику. Сличност им је у томе што се и за једна и друга тражи живо врело друштвено: код Балија у разговорном књижевном језику, а код Вука - у народном јзику извесних језичких просторија нашег народа. Када би становништво тих просторија, место да говори својим народним дијалектом, употребљавало разговорни књижевни језик, што ће, вероватно, једног дана и бити, онда би нестало сваке разлике између концепције Балијеве и Вукове. Овако извесна разлика међу њима постоји; али је принципска истоветност у главним цртама њиховим. Код Вука је творац поменутих језичких критерија народ - исто тако колективна јединица као што је код Балија класа културнијег становништва. У употреби својих језика и једна и друга је средина слободна и творачка, неограничена ничим другим до прећутним пристанком друштвене и народне средине који се огледа у општем примању дотичне црте" (Белић 1998: 545).

б) И Белићу и нама импонује поређење српских и француских прилика, српске и француске културе, те и развојних тенденција књижевог језика. Али Белић на овој линији није сасвим у праву у ономе што сматра аргументом. Наиме, српски народни језички идиом на чијој је основици изграђен Вуков књижевни језик, па ни народна књижевност као 
уметнички израз тога идиома, практично остају изнад домена културне комуникације поствуковског доба и не утичу, или боље рећи не утичу битније, ни на физиономију ни на правце развоја књижевног језика све до XX века. Књижевнојезичке прилике од половине, а нарочито од краја XIX века, ствар су деловања уметничке књижевности, школства, привремено против језика администрације, па и науке, трајно против цркве итд. Тако је код Срба, „крајем прошлог [=XIX] века, са коначним формирањем књижевног језика, извршено 'скопчавање' читавог развојног ланца и успостављен пуни континуитет" (уп. Симић 1991: 352-391; 390).

2.3. Али Белић је сам успео другом приликом допунити своје истраживање и прецизирати погледе, и пратећи развој српскога књижевног језика у XX веку да нађе његово језгро у којем почиње паралелан живот са француским језиком.

a) Наиме, у поређењу са француским приликама - вредно је помена Белићево гледање на српски књижевни језик као укупно средство комуникације не дијалекатских говорника, већ једног слоја народа који се у међувремену учврстио као економски и културни врх српске нације. У дефинисању тога процеса у којем настају нови односи и настаје нов језички идиом, - који он назива 'београдским стилом', - Белић (1999: 121-122) упозорава на ширину дијалекатске основице која чини подлогу књижевног језика, и која се слива у језички трезор његовог културног средишта - Београда.

б) Вуково начело 'пиши као што говориш' погодовало је формирању те језичке матице која је усмеравала токове према средишту: „Ваљало се држати само оних општих граматичких облика које је имао Караџићев језик и писати у духу свога матерњег језика. Та заједница духа народног језика [...] чини да су и у Вукову језику [видљиве] клице 'београдског стила', исто онолико колико и у Бранкову, Јакшићеву, Лазаревићеву, Змајеву или Дучићеву".

в) Но прави 'београдски стил' утврдио се тек код генерација писаца рођених у интелектуалним срединама у којима је књижевни језик постао говорни, прво наравно у београдској:

Београдски језик и стил створио је београдски живот и живот самог књижевног језика у Београду. Када су се у Београду почела јављати поколења писаца чији је матерњи језик био књижевни језик... - онда је књижевни језик почео живети у делима њиховим - животом народног језика. Он је постао жив и творачки, гибак и савитљив, увек спреман да пође даље у своме развитку [...] (Белић 1999: 122). 
г) Одавде следи заправо мисао да се српски књижевни језик у доба кад је српска политичка престоница постала прави културни центар са књижевношћу која настаје у круговима чији је матерњи језик књижевни - по статусу и главним цртама изједначује са француским и другим европским језицима. Тада су бајијевска разматрања могла добити пуну важност и у српској језичкој средини.

3. Када промотримо Рисове ставове, постаје јасно да он у центру пажње има језик као систем, и општа својства његових елемената с обзиром на однос према неком доминантном критерију - по свему судећи овде је реч о норми. Шарл Баји, узимајући у разматрање такође језички систем као битну скупину чињеница којима се бави наука о језику, износи став да његови елементи варирају у једној области на коју Рис не обраћа пажњу: то је област емоционалних одлика знака. Стилистика се по Бајију занима за емоционалну, одн. афективну страну језика и његових знаковних јединица. Сасвим из другог угла на језички знак гледа Л. Шпицер.

3.1. Прво његово дело о којем желимо нешто рећи („Stilstudien I-II”) углавном садржи студије о романским језицима (првенствено француском) и језику романских писаца (опет углавном француских), уз додатак једне посвећене општим питањима 'уметности речи и науци о језику'. Предмет нашег приказа биће углавном овај програмски конципиран рад.

a) Идући за Фослеровим схватањем о језику као индивидуалној појави у којој се огледа људски стваралачки дух, Шпицер (1927: 517-519) износи тврдњу по којој „општи језик није ништа друго до просек индивидуалних језика, [чине га] граматикализирани различити говорни чинови - а поетски чин није ништа друго до говорни чин. Свака новина долази од појединачног стваралачког чина: nihil est in syntaxi quod non fuerit in stylo; синтакса, као и граматика није ништа друго до залеђена стилистика. Мноштво онога што је обрађено у чувеној Тоблеровој књизи 'Gemischte Beiträge zur francösischen Grammatik' - било најпре стилистичка новина [...], у довољној мери објашњива из литерарног импресионизма и његове тежње да саопшти тачне чулне квалитете”.

Две латинске реченице стало ми је да истакнем као мото мојих стилистичких истраживања: 'individuum non est inefabile' - индивидуални стилски језик може се описати управо методима науке о језику; - и: 'oratio vultus animi's - тај индивидуални језик је неопход-

4 'Wortkunst und Sprachwissenschaft': II, 498-536.

5 Дословно: 'говор је израз душе'. 
на природна последица деловања појединачног духа. Могло би се за последњи став узети крилатица 'Le style est l'homme', да Бифон на одговарајућем месту свог 'Discours sur le style' 'le style est l'homme même' није употребио у сасвим друкчијем смислу.

Индивидуални творачки акт, који у избору и употреби јединица ради изградње тренутно употребљених структура не мора у свему одговарати узуалним захтевима датог језика, представља темељну стилску чињеницу, из које 'граматикализацијом', тј. учвршћивањем у језичком систему и у језичкој пракси, настаје 'језичка чињеница'.

б) Поводом Валцелових (Oskar Walzel) примедаба против психологизма, Шпицер формулише неке од својих чувених методолошких глоса, од којих је прва и најзначајнија да аналитичар књижевног дела мора кренути из његовог средишта, па у сваком случају посебно пронаћи трансверзале по којима ће истраживати његову суштину. „Материјалистички, од стране Крочеа исмејани биографизам, бављење вањским ситницама из пишчевог живота, не намеравамо поново оживљавати. Али зар није духовна биографија, опис духовног бића у мери у којој се оно у делу испољава, зар то није вредно научне пажње и неопходно за разумевање дела?"

И зар није у ономе 'und' ['и'] у наслову Валцелове књиге 'Gehalt und Gestalt' ['садржај и форма'] међу овима назначена једна релација, а с њом и могућност обрнутог тумачења: од форме према садржају? Такође се залажем за неку еластичнију методу истраживања књижевне уметности него што је Велфлиново [Wölfflin] учење о категоријама, и то из двојаког разлога: јер ово оверава књижевно дело по категоријама наметнутим споља, према такорећи ексцентричним поларитетима пренесеним на језичку уметност са ликовне, - док ја, тражим да упознам стил пишчевог језика преко лектире његових радова, посебне законитости његове искључиво из њега самога (нпр. припремајући своје анализе ја не знам унапред где је централно место појединог личног стила). Читати, пажљиво читати - јесте такорећи моја једина занатска вештина (Шпицер 1927: 518).

3.2. У другом свом делу Шпицер (1962: 18-19) потврђује своја схватања о научној методологији стилистике како је он схвата. Развија тезу о 'вањској' и 'унутрашњој форми', центру и периферији, и препоручује опет полазак из центра при анализи дела. 
Не може се друкчије, него језик схватити као спољашњу кристализацију 'унутрашње форме'; или да употребимо друкчију метафору: животна крв поетског дела свуда је једнака, било да организам посматрамо са 'језичке' стране или са стране 'идеја', као 'материјал' или као 'композицију' Тако сам и ја, у крајњој линији, пошао такорећи од голе књижевне композиције Раблеових списа, и тек касније прешао на његове идеје, његов материјал, његов језик. Наиме, ја сам лингвист и почео сам из лигвистичког угла и пронашао пут до целине. Свакако, од осталих проучавалаца нико није обавезан да чини исто. Оно што свако мора чинити, верујем, јесте да крене од површине ка 'унутрашњем животном средишту' уметничког дела: прво ваља посматрати појединости површинске појавности појединачног дела (а 'идеје' изражене од стране песника такође су само део површинске анализе уметничког дела); затим груписати те детаље и покушати да се интегришу у стваралачке принципе који су по могућности настали у уметниковом духу; и на крају, вратити се свим анализираним појединостима са циљем да се утврди да ли је 'унутрашња форма' складно изграђена као целина. Теоретичар је свакако у стању, након три или четири покушаја, да се пробије до животодајног центра, до средишта соларног система (при томе ће утврдити да ли је он стварно инсталиран у средишту дела, или се налази у'ексцентричној' или периферној позицији).

3.3. Ширину Белићевих интересовања за граничне проблеме лингвистике и стилистике још нисмо до краја сагледали. Потребно је скренути пажњу и на друге теоретичаре који се групишу око ове тематике и који су утицали на Шпицера. Један од њих је и Бенедето Кроче, кога Белић помиње више пута, а ми ћемо указати на један рад са карактеристичним насловом „Дух народа и дух језика” (Белић 2000: 565-568).

a) Прво Белић износи срж Крочеова учења: „За њега је свака права претстава, добивена непосредним стварањем, интуицијом - у исто време и онај знак којим је та претстава изражена. То је једна целина. Човек је онолико способан за интуитивно сазнање колико може језиком да оствари. По Крочеу онога чега нема у изразу нема ни у стварању, у интуицији. Ако коме изгледа да не може да нађе израза за оно што се у његовој души створило или ствара за Крочеа је проста самообмана: у ствари, у души таквог књижевника или уметника ништа се не ствара. Да је тако нешто било, оно би добило свој израз”. Затим Белић у вештим формулацијама оправдава Крочеове ставове: 
Нема сумње да у овом закључку или ако хоћете, у теорији Крочеовој има онолико истине колико може бити уопште у уопштавањима која сложене процесе своде на сасвим просте појаве. Све зависи од тога да ли је он у својој генерализацији уопштио оно што је најважније у језичком стварању. Очигледно да језик није онолико индивидуалан колико би то излазило из овако апсолутно схваћеног интуитивног сазнања, већ да и само друштво утиче на поједница, исто онако као што појединац утиче на целину. Али није питање да ли је Кроче својом дефиницијом обухватио све што би се могло рећи о језичком стваралаштву, већ да ли је у своме упрошћавању и свођењу његових елеманата нашао ону искру која може да потстакне светлост којом би се целина језичког стваралаштва, у којем је дух језика у потпуности оличен, - могла осветлити. Ја мислим да у томе правцу не може бити сумње у тачност Крочеова схватања. То нам показује свако непосредно испитивање и појединачног језичког стварања и колективног, узетих било као обележје једног књижевника према другом или једног народа према другим народима.

б) Ако се под 'језичким стварањем' разуме уметнички творачки акт, куда је Белић скренуо правац расправе, онда је Фослерово и Крочеово учење без даљњег прихватљиво. Но нас овом приликом више занима чињеница да је оно што се овде сматра 'стварањем' - заправо стилски поступак у обликовању књижевног дела. Друга је ствар што у сваком случају употребе језичких потенцијала, чак и у најпростијем говорном акту, можемо открити зрнце стваралаштва - и што је по Бифоновом схватању и ту уложен напор стилског активирања језичких средстава.

4. Јасно је да је стилистичке теоријске мисли својих претходника и савременика Белић умео зналачки инвентивно уграђивати у своју општелингвистичку визију, - па ћемо сада, и након кратког прегледа тих идеја, опет само укратко бацити поглед и у Белићеву лингвистичку радионицу, и погледе које је тамо исказивао, а који се са гледишта данашње науке могу сматрати стилистички релевантним.

4.1. Посебно је важно истаћи Белићево схватање појма 'јасноће', коју он објашњава чисто лингвистичким путем, а која је у првом реду фактор аристотеловски схваћене реторичке, одн. по данашњем схватању стилски ефицијенцијске вредности (Симић 1997). „Главна одлика стила” јесте јасноћа, јер „нејасна беседа не може постићи свој циљ” (Аристотел 1987: 205).

a) А. Белић је јасноћу тумачио потребом „да свака претстава и сваки појам буду обележени или, боље да речемо, диференцирани групама гла- 
сова које су што је могуће мање између себе сличне”. Даље, постављајући у обрнуто пропорционалном односу тзв. етимолошку и актуелну јасноћу - Белић говори о двојакој могућности еволуције речи с обзиром на однос ознаке и означеног садржаја. Пошто је примарно 'парцијална' ознака једног елемента значења ('рука' је примарно значило 'скупљачица)', она је у развојном процесу добијала могућност да постане 'тотална' ознака, тј. да упућује на целину предмета, поприма отуда што својом 'апстрактношћу', и ослонцем на ситуацију, шири асоцијативно поље на мноштво разноврсних предметних јединица.

Тако белаи може значити 'коња', 'човека беле расе' и још много штошта друго јер његова различна значења дају непрестано могућност везивања са детерминативом ('бео'). С друге стране, реч нпр. дом упућује на одређени предметни садржај никако не инсистирајући на његовим особинама (по Белићу, она их даје у 'збиру'), иако је по пореклу управо ознака са једностраном асоцијативном везом под чијом је заштитом првобитно упућивала на предмет (Белић 2000: I, 270).

б) Проучавајући језике различитих структурних типова, Белић, у складу са тадашњим општим схватањима, и сам издвајајући посебне перспективе вредновања, истицао је предности флексијског типа, како у функционалном, тако и естетском и стилском погледу, јер је био чврсто уверен да се „у томе види тежња ка јасности и прецизности. И сви језици - аргументује Белић (1998: 273) - који граде велико мноштво различних облика или сличних помоћних средстава - чине то из исте тежње. Одавде се види присна веза лингвистике са естетиком и стилистиком. Ако су индоевропски језици развили мноштво формалних елемената, знатно више неголи многи други језици у свету, они зато имају унутрашњу јасноћу и провидност којом се не могу похвалити сви језици света." Његов осећај о већој 'јасноћи и провидности' језика са развијенијим и чвршћим морфолошким системом врло је значајан аргумент.

4.2. Толико је довољно да стекнемо увид у Белићева интересовања за стил и стилистику, а и у значајна научна збивања у првој половини XX века на пољу науке о стилу. Стилистика је схватана врло различито, и у систему наука приписивано јој је различито место, - али су приметне две основне тенденције у тим настојањима.

a) Што се тиче првог, видна су два основна правца посматрања: једно је покушај свођења стилистике на праћење стања језичког система и његове варијације, боље рећи: одступања од идеалног схватања о избору 
и употреби језичких јединица. Друго је праћење душевног стања онога ко исказује дату језичку структуру.

б) По првом изложеном схватању, стилистика је сматрана делом естетике и науке о књижевности, а по другом - стилистика је део лингвистике како је схвата Де Сосир.

\section{3. Закључне напомене}

1. Белић је приказао два случаја лингвистички оријентисаних стилистичких истраживања.

a) Код J. Риса стилистици је приписан задатак да се бави приземним проблемима исправности израза и правилности употребе фонолошких, морфолошких, синтаксичких и других јединица у књижевном језику.

б) Шарл Бали је засновао тзв. афективну стилистику свакодневног језика француског вишег друштва, тј. оних друштвених слојева који у свом изразу употребљавају говорне варијације књижевног француског језика. Белић с правом упућује на разлику француског и српског језика указивањем на разлику у пореклу и ширини употребе књижевног језика, али том приликом пропушта да укаже на разлику у понашању већине говорника према књижевнојезичкој норми: једни се понашају према њој као наддијалекатском средству културне комуникације, а други као према оплемењеном дијалекту с којим је књижевни језик у сталној кореспонденцији, обнављајући се и подмлађујући позајмицама из дијалекатске базе. Но каснијим размишљањима Белић долази и до језгра које српску ситуацију у дато доба српске културе изједначује са француском. То је време настанка 'београдског стила', када се у књижевности јављају писци чији је 'матерњи језик' - књижевна реч.

2. У мноштву данашњих идеја о стилу и стилистици запажају се заправо одјеци обеју оцртаних тенденција, с тим што је стилистици дато право да се бави како књижевним језиком тако и свим нестандардним, тј. надстандардним и супстандардним појавама. При томе се језик књижевности у начелу издваја из корпуса стандардних варијетета, јер слобода избора у књижевном делу прекорачује норму у свим правцима посматрања, иако се мора признати да је то једна од радионица у којима се стваралачки употребљава и усавршава језик као општа људска појава, док се стандардним могу сматрати само они варијетети који су нормативистички обрадиви и доступни контроли, нпр. језик школства, језик администрације, донекле језик науке итд. 
3. Што се тиче сопствених Белићевих погледа на језик, нека од њих, утврдили смо, имају посебан значај за разумевање оних особина језика у систему и употреби која се у данашње време сврставају у стилистичку проблематику.

a) Једно од њих тиче се квалитативних својстава језика уопште. То је 'јасноћа', основни појам Аристотелове реторичке мисли, који се може уградити у стилистички систем појмова срачунатих на 'оптималност учинка' језичких знакова у употреби, и својстава која томе доприносе.

б) Друго Белићево схватање релевантно за стилистичку науку, а које се тиче српског књижевног језика, али не само српског, - везано је за појам 'београдског стила'. Белић утврђује да је сувереност овладавања књижевним језиком тек онда у правом смислу реална, кад је припадник језика овладао њиме као матерњим идиомом. То се десило са српским књижевним језиком тек кад је он у Београду и у другим урбаним срединама постао својствен генерацијама природних говорника. Тек књижевник, а и сваки појединац, рођен у таквој средини способан је да стваралачки употреби његове потенцијале.

\section{ЛИТЕРАТУРА}

Аристотел 1987: Аристотел, Реторика 1/2/3, Београд: Независна издања.

Баји 1951: Ch. Balli, Traite de stilystique française, Heidelberg.

Белић 1999: А. Белић, Око нашег къижевног језика, Београд: Завод за уџбенике.

Белић 2000а: А. Белић, О језичкој природи и језичком развитку I, Београд: Завод за уџбенике и наставна средства.

Белић 2000б: А. Белић, О различитим питатима савременог језика, Београд: Завод за уџбенике и наставна средства.

Puc 1927: J. Ries, Was ist Syntax, 1894. - 2. Aufl., Heidelberg

Симић 1993: Р. Симић, Лингвистика стила, Никшић: Унирекс.

Симић 1997: Р. Симић, Увод у филозофију стила, Београд: Универзитет у Београду.

Симић 2001: Р. Симић, Опита стилистика, Београд: Научно друштво за неговање и проучавање српског језика.

Симић 2010: Р. Симић, Стилистика српског језика I. Фоностилистика, 2. изд., Београд: Јасен. 
Шпицер 1961: L. Spitzer, Stilstudien I-II, 1927. - 2. Aufl., München: Huebrverlag.

Шпицер 1962: L. Spitzer, Linguistics and Literary History. Essais in Stylistics, Princeton University Press. - 2. Aufl., New York: Russel and Russel.

Jelena Jovanović Simić

\author{
ALEKSANDAR BELIĆ ON THE STYLE, AND THE STILISTICS OF THE SERBIAN \\ LANGUAGE \\ Summary
}

In this paper, the author tried to reduce Belićs's perceptions to a unique common content, which can be obtained by reading the most important of his style studies, the 'Belgrade style' and 'clarity in language'. In addition, the author gave a presentation of Belićs works on the stylists of the beginning of the XX century, and on only two names - J. Ries and Ch. Balli, - and supplemented them with notifications of B. Kroce. About L. Spitzer Belić did not give out wider notifications, but since it was written about him, or otherwise little, he came to his place in his consideration. 